Мирјана Чутовић

Универзитет у Крагујевцу

Учитељски факултет Ужице

Сара Савчић

Универзитет у Београду

Филолошки факултет
UDC: $316.774: 004.738 .5$

UDC: $371.3:: 821]: 004.738 .5$

DOI: 10.18485/dh.2015.2.ch7

\title{
ДРУШТВЕНЕ МРЕЖЕ У СЛУЖБИ КЊИЖЕВНОСТИ И КУЛТУРЕ
}

\section{Сажетак}

Друштвене мреже су, као релативно ново откриће, изузетно брзо узеле маха у свету. Стварна корист и употреба ових мрежа увек је дискутабилна, највише због њиховог неконтролисаног али и неадекватног начина коришћења од стране млађе популације, ипак, оне су у многоме помогле људима да напредују у послу. Друштвене мреже никако нису зобишле ни промоцију културе, језика и књижевности и тиме омогућиле лакшу и бржу доступност занимљивим и актуелним садржајима у њиховом домену. Овај рад ће се бавити оним што аутори сматрају правилним начином коришћења друштвених мрежа и социјалних медија у домену културе, књижевности и уметности са циљем очувања, развоја, али и даљим иновацијама у оквиру истих.

Кључне речи: друштвене мреже, иновација, култура, књижевност

\section{Увод}

Једна од важних карактеристика нашег модерног друштва је интензиван развој науке и технике. Информациона технологија је ушла у све области људског деловања. И у школама, конкретно, у настави, која, по много чему, још увек има ознаке традиционалног, неопходно је интензивирати њену примену. Као релативно ново откриће које је изузетно брзо узело маха у свету јесу друштвене мреже. Почев од Фејсбука ${ }^{1}$, који је осмислио бивши студент Харварда Марк Закербер, 2004. године, искључиво за потребе колеџа на Харварду (Василијевић, 
118), нижу се социјалне мреже попут Твитера ${ }^{2}$, Инстаграма $^{3}$, Линкди-

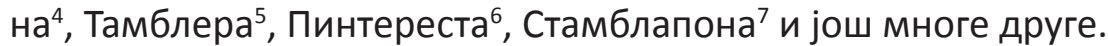

Мада је стварна корист и употреба ових мрежа увек дискутабилна, највише због њиховог неконтролисаног и у већини неадекватног начина коришћења од стране млађе популације, ипак, оне су у многоме помогле људима да напредују у послу. Или чак осмисле сопствени, лакше прате актуелна дешавања и готово увек буду са свим оним што их интересује.

На срећу, друштвене мреже никако нису зобишле ни промоцију уметничких и културних садржаја и тиме омогућиле лакшу и бржу доступност занимљивим, модерним (и не само модерним) садржајима у њиховом домену.

\section{Фејсбук у образовању}

„Савременаобразовнатехнологија,узкоришћењемултимедијалних система, ствара предуслове за ангажовање свих чула у процесу стицања нових знања на свим нивоима школовања" (Богдановић, 219). Фејсбук има изузетно велики капацитет дневног протока информација и као таква друштвена мрежа позитивно може да користи младим људима у оном моменту када траже брзу, сигурну и актуелну информацију. Родитељи би заједно са образовним институцијама могли да имају велику улогу у развијању техничких компетенција код младих када је реч о употреби компјутера и информационих технологија․ Школе код нас у овом моменту још увек имају готово маргиналну улогу када је реч о образовању за информационе технологије. Брз развој информационо комуникационих технологија створио је услове за коришћење информационо комуникационе технологије и у нашим школама. Нове технологије су донеле и

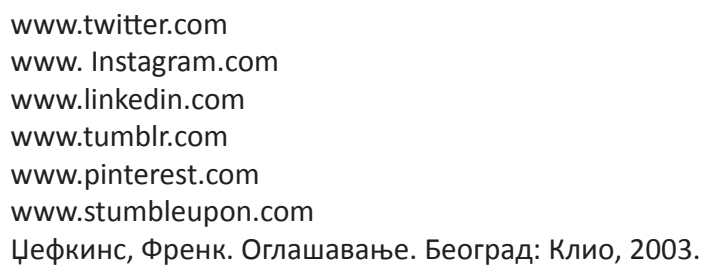


нове могућности за презентовање и усвајање наставних садржаја, из разних области у скоро свим предметним областима наставе, тако да су актуелност и значај примене информационо комуникационих технологија у настави постали важно питање које привлачи пажњу како теоретичара који се баве питањима наставе, тако и практичара који су непосредно укључени у наш образовни школски систем. „А кад се једна технологија потпуно исцрпи“, рекао је Вилотијевић, „морају се уводити нове јер настава не сме остати на досад постигнутом“ (8). Да би се настава актуализирала, потребно је увести иновације у образовање. Реч је о увођењу новина у васпитно-образовни рад које се најчешће односе на примену нових метода, поступака, средстава, концепција наставних садржаја или наставних програма (Митић, 21). Једна од иновативних могућности за унапређење наставног процеса јесте електронско учење. Реч је о учењу у коме је ученик ангажован и активан у наставном процесу. Електронско учење представља читав „низ поступака, процеса и наставног материјала који обезбеђују разноврсност и ефикасност учења“ (Бјекић, 13). Обзиром на то да представља једну од најпопуларнијих социјалних мрежа на свету, образовне институције су почеле користе Фејсбук у сврхе образовања. Схватајући да ученици већину слободног времена проводе на интернету, решили су да се модернизују и приближе градиво на занимљив начин. Створене су бројне апликације, профили, фан странице, групе преко којих ученици међусобно или са својим професорима комуницирају, размењују идеје, ставове, искуства, итд.

Данас је изузетно тешко направити ваљани баланс и бити у могућности да се испрате сва дешавања код деце, мада се сви трудимо. Живи се брзим темпом, доступност је постала неприкосновена, а приватност мисаона именица. Виртуелни свет је узео маха и готово је постало немогуће живети и функционисати ван домета технологије.

\section{О друштвеним мрежама у служби промоције културних садржаја и институција}

Посебан значај друштвених медија огледа се у погледу промоције културе и културних садржаја. Повећање ефикасности и 
брзине Интернета последњих неколико година, омогућили су наглу експанзију друштвених медија који представљају несумљиви феномен сајбер садашњице. Друштвени медији почињу да се развијају почетком 20. века са појавом и развојем блогова и Википедије. Платформу на којој се заснивају друштвени медији, карактеришу отвореност, слобода и колективна интелигенција9. На основу ње, настали су јединствени сервиси и алати за комуникацију на Интернету око којих се окупља највећи број корисника Интернета. Очигледно је да су друштвени медији један од најновијих примера комуникационих технологија које су широко усвојене од стране ученика и, последично, постају драгоцени ресурси који би подржали образовне комуникације и сарадњу ученика. „Упркос бројним дискусијама о друштвеним медијима, које било да су фокусиране на веома прозаичне или веома битне аспекте, расте број просветних радника који почињу да разматрају могући значај и утицај друштвених медија на образовну праксу (Арсовић, 471).

Око порекла самог термина друштвени медији (енгл. social media) не постоји концензус. Постоји више аутора који себи приписују стварање овог термина који се у нашој земљичесто погрешно преводи као социјални медији уместо друштвени медији. Друштвени медији укључују све врсте он-лине технолошких алата који омогућавају корисницима да комуницирају и деле бројне садржаје, текстове, слике, звучне и видео записе.

Најпопуларније друштвене мреже су Фејсбук, Линкдин и Мајспејс ${ }^{10}$. Блогови представљају врсту сајта који омогућавају да један или више аутора објављују садржаје (текстове, слике, звучне и видео записе) у форми чланка (блог пост) који су доступни другим корисницима и обично приказани у обрнуто хронолошком редоследу. Интернет форуми су најстарији тип друштвених медија и представљају места за дискусију људи на одређене теме или места за савете и размењивање вести. На сваком форуму постоје модератори који воде рачуна о садржају и који бришу неприкладан садржај.

9 Ранковић, Милан. Социологија уметности. Београд: Уметничка академија, 1967.

10 www.myspace.com 


\section{Друштвене мреже усвојене од стране културних установа}

Виртуелни светови су заједнице које користе компјутерске симулације окружења у којем корисници бирају графички изглед који ће их представљати (аватар) и у којем могу да ступе у контакт једни са другима и да стварају и употребљавају објекте. С обзиром на брз развој друштвених медија који окупљају највећи број корисника широм света, друштвени медији постали су саставни део интегрисаних маркетиншких комуникација. И културне установе усвајају друштвене медије у своје планове комуникације. Културне установе, које обично имају мањи број запослених у односу на комерцијална предузећа, морају да буду веома економичне и да изаберу оне друштвене мреже које ће им донети највише успеха код њихових циљних група. Маркетинг на друштвеним медијима представља тежак подухват с обзиром да корисници друштвених медија не воле отворене комерцијалне поруке. Основна правила маркетинга на друштвеним медијима су аутентичност и транспарентност. Културне установе имају задатак да пручавајући своје циљне групе изаберу одговарајуће друштвене медије и да пре свега предњаче у излагању идеја својим корисницима. Стварајући бројне везе да другим културним установама развијају и своју нову потенцијалну публику. Он-лине комуникација, као и свака комуникација, представља процес, а не активност која се састоји од неколико фаза, од којих је међу првим и основним - образовање.

Друштвене мреже карактерише отвореност структуре тако да је критеријум уласка у мрежу једноставан. Можемо их дефинисати као сервисе базиране на Вебу који дозвољавају појединцима да креирају јавни или полујавни профил и да састављају листу контаката са којима желе да комуницирају. Из ових дефиниција можемо закључити да су друштвене мреже квалитетни преносиоци постојећих и новокреираних садржаја, што их већ чини посебним медијима. Друштвене мреже омогућавају успостављање и одржавање хоризонталне комуникације.

\section{Фејсбук у служби културе}

Према истраживањудруштвенихмрежа лидерскупозицијудржи Фејсбук са милијарду активних корисника. У Европи су најпопуларније 
друштвене мреже Фејсбук, Линкдин, Твитер и Баду. ${ }^{11}$ У наставку рада представићемо карактеристике и могућности Фејсбука за културне институције с обзиром да је ова мреже најпопуларнија како у свету тако и у Србији.

Фејсбук је данас најважнија друштвена мрежа која окупља око милијарду људи широм света. Овај медиј покренут је 2004. године са циљем да повеже најпре студенте у Америци, а касније и људе широм света са својим пријатељима, колегама и породицом. Временом се поменути сервис развијао заједно са потребама људи и данас Фејсбук као најпосећенији сајт у свету и у Србији постао је изузетно важан инструмент у маркетиншким комуникацијама.Занимљиво је запажање теоретичара да ниједан медиј у историји није имао такав успех и брз развој као Фејсбук. Успех Фејсбука се мери и чињеницом да су се корисници везали за ову друштвену мрежу

Културне институције могу веома лако да креирају страницу на Фејсбуку али то данас није довољно. У савременом свету готово све компаније, брендови и културне институције поседују фан паге и покушавају да привуку и вежу за себе што више посетилаца. Културна институцијаморада пажљиво осмислистратегију комуникацијена овој друштвеној мрежи. Наиме, културне институције често заборављају да корисници Фејсбука желе интересантне информације а не просто рекламирање догађаја институције. ${ }^{12}$ Из тог разлога културним установама саветује се да буду што креативније на Фејсбуку и да се труде да постављају садржаје који могу да пробуде интересовање или чак и могућу реакцију. Без обзира да ли културна институција промовише класичну или савремену уметност неопходно је да обраћање на Фејсбуку буде директно, неформално и да се чланови странице питају за мишљење. Фејсбук омогућава културним институцијама директну двосмерну комуникацију. Објаве на зиду (енгл. пост) требају да буду кратке и да евентуално воде на веб институције где корисници могу да прочитају више информација. Саветује се постављање једне или две објаве дневно. Уколико културна институција има више информација саветује се да их објављује на свака два сата.

11 Колбер, Франсоа. Маркетинг у култури и уметности. Превела Јелена Томашевић. Београд: Клио, 2010.

12 Мирман, Скот. Нова правила маркетинга и односа с јавношћу. Београд: Микрокњига, 2009.

94 
Менаџер за друштвене мреже има задатак да привуче што већи број посетилаца. За привлачење нових чланова на Фејсбук страницу могу се користити следеће методе: Позвати постојеће контакте са профила администратора. Послати позивно писмо, њузлетер, свим члановима у бази контаката. Направити приступну страницу на Фејсбуку. Спровести офлајн кампању Фејсбук странице. Поставити банере на сајт који воде директно на страницу. Повезати се са сличним културним институцијама на Фејсбуку и редовно коментарисати њихов рад. Захвалити новим члановима на придруживању страници. Омогућити попусте за чланове странице или могућност резервације улазница. Од изузетне је важности да менаџер за комуникације или друштвене мреже редовно одговара на сва питања члановима странице.

Културне институције имају могућност спровођења конкурса и промоција на Фејсбуку, али приликом њиховог организовања неопходно је бити изузетно пажљив. Наиме, крајем 2010. године Фејсбук је променио правила везана за конкурсе и промоције и више није дозвољено организовати конкурсе директно на овој друштвеној мрежи. Данас да би се реализовали конкурси неопходно је користити апликације креиране од стране трећих лица.

\section{Закључак}

Будући да је сад већ извесно како живимо у свету у којем полако почиње да преовладава виртуелни свет заједно са друштвеним мрежама, као и да је од те чињенице сад готово немогуће побећи, не преостаје ништа друго него да из ове иновације, која вртоглаво напредује из године у годину, покушамо и извучемо само оно најбоље. Вредело би покушати и извући оно добро и корисно из света Интернета и друштвених мрежа који су постали саставни део свакодневног живота деце и одраслих, те нема боље сфере од формалног образовања са којим бисмо могли почети. Засигурно је могуће обгрлити њене врлине и припитомити је тако да буде у служби формалног образовања, као и промоције уметничких и културних садржаја и институција. 


\section{Литература}

Адижес, Исак. Менаимент за културу. Превели Бранислава Допуђа и Небојша Царић. Нови Сад: Graph style, 2006. Print.

Арсовић, Бранка. „Друштвене мреже - изазов и могућност за образовање“. Техника и информатика у образовању 2012: зборник. Приредио Драган Голубовић. Чачак: Факултет техничких наука (2012): 469-478. Print.

Бенет, Питер. Dictionary of marketing terms. Чикаго: American Marketing Association, 1995. Print.

Бјекић, Драгана. Психологија учења и наставе у електронском образовању, Чачак: Факултет техничких наука. (2013). Print.

Богдановић, М. (2012). Учење и савремена информационо комуникациона технологија. Годишњак Српске академије образовања, година: VIII, str. 219230. Print.

Василијевић, Данијела. „Друштвене мреже у образовању“. Годишњак Учитељског факултета у Врању, књига VI, (2015): 117- 126. Print.

Драгићевић - Шешић, Милена, и Бранимир Стојковић. Култура, меначмент, анимација, маркетинг. Београд: Клио, 2003. Print.

Ђорђевић, Живорад. Увод у новинарство. Београд: Центар за савремену журналистику 2005. Print.

Ђорић, Михаило, Комуникација и нови медији, ЦЕТ Читалиште, бр. 67, новембар 2007. Print.

Кобас, Дијана. Односи сјавношћукао деомаркетиншког микса. Маркетингупракси: Часопис за тржишне комуникације 9 (2002). Web. 14 apr. 2016.

Колбер, Франсоа. Маркетинг у култури и уметности. Превела Јелена Томашевић. Београд: Клио, 2010. Print

Мирман, Скот. Нова правила маркетинга и односа с јавношћу. Београд: Микрокњига, 2009. Print.

Митић, Војислав. Психолошки чиниоци прихватања иновација у настави. Нови Сад: Будућност, (1999). Print.

Павичић, Јурица. Стратегија маркетинга непрофитних организација. Загреб: Масмедиа, 2003. Web. 14 apr. 2016.

Пик, Џон. Managing the arts? The British Experience. Лондон: „Rhinegold“, 1986. Web. 16 apr. 2016.

Ранковић, Милан. Социологија уметности. Београд: Уметничка академија, 1967. Print.

Филиповић, Винка, и Радмила Јаничић. Стратешки маркетинг. Београд: ФОН, 2010. Print.

Томић, Бобан. Увод у медије. Београд: Чигоја, 2012. Print.

Џефкинс, Френк. Оглашавање. Београд: Клио, 2003. Print 


\title{
Mirjana M. Cutovic
}

University of Kragujevac

Teachers College in Uzice

Sara Savcic

University of Belgrade

Faculty of Philology

\section{SOCIAL NETWORKS IN THE SERVICE OF LITERATURE AND CULTURE}

\begin{abstract}
Summary
As a relatively new discovery which rapidly expanded in the world are social networks. Starting with Facebook, social networks such as Twitter, Instagram, Linkedln, Tumblr, Pinterest, Stumbleupon and many more, continued to flare. Although the actual benefit and use of these networks are still controversial, mainly due to their uncontrolled and in most inadequate way of usage by the younger population, however, they have greatly helped people to progress in work, or even design their own, to easily monitor current events and almost always be updated regarding all that interests them. Fortunately, social networks did not forget the promotion of culture, language and literature, thus enabling easier and faster access to new, modern (and not only modern) contents in their domain. This paper will deal with what the authors believe the proper way of using social networks and social media is, in the field of culture, literature and arts with the aim of preservation, development, and continuation of innovation within them.
\end{abstract}

Key words: social networks, innovation, culture, literature, promotion 